\title{
Evaluation of climate change impacts on reference evapotranspiration under RCPs scenarios in Northern Greece
}

\author{
Koukouli P.*, Georgiou P.E. and Karpouzos D.K. \\ Department of Hydraulics, Soil Science and Agriculture Engineering, School of Agriculture, A.U.Th, Thessaloniki, Macedonia, Greece \\ Received: 19/12/2018, Accepted: 04/06/2019, Available online: 05/06/2019 \\ *to whom all correspondence should be addressed: e-mail: pkoukoul@agro.auth.gr
} https://doi.org/10.30955/gnj.002998

\section{Abstract}

Reference evapotranspiration (ETo) is an important component in water resources, agricultural and environmental modeling, thus its assessment is critical in understanding the impacts of climate change on the sector of agriculture. In this study, the effect of climate change on reference evapotranspiration in Northern Greece, was assessed. For this purpose, the climate change scenarios RCP2.6, RCP4.5 and RCP8.5 based on four Earth System Models (ESMs) CanESM2, GFDL-ESM2M, HadGEM2-ES and IPSL-CM5A-LR were used for the time periods 2041-2060 and 2081-2100 and for the baseline period (1981-2000). Reference evapotranspiration was estimated with the use of the FAO Penman-Monteith equation. Results showed that mean annual $\mathrm{ET}_{\mathrm{o}}$ is projected to increase in response to climate change during 2041-2060 and 2081-2100 according to the four ESMs with the greater increase predicted by the end of the $21^{\text {st }}$ century. The increase in $\mathrm{ET}_{0}$ is driven mainly by the temperature rise and secondly by the solar radiation increase in the future. The results indicate that the development of adaptation strategies is necessary for the improvement of agricultural water management and the reduction of climate change impacts on agriculture.

Keywords: Climate change, reference evapotranspiration, RCPs, Earth system models.

\section{Introduction}

Climate change is considered a major problem worldwide and its impacts on different aspects of social activity and on the natural environment require careful assessment. Scientists are more than $90 \%$ certain that warming of the climate is primarily caused by increasing concentrations of GHGs - greenhouse gases $\left(\mathrm{CO}_{2}, \mathrm{CH}_{4}, \mathrm{O}_{3}, \mathrm{CFCs}\right.$ and Nitrous oxide) produced by human activities such as the burning of fossil fuels and deforestation (IPCC, 2007). Warming of the climate system in recent decades is unequivocal, as is now evident from observations of increases in global average air and ocean temperatures, widespread melting of snow and ice, and rising global sea level (IPCC, 2013). Net anthropogenic radiative forcing of the climate is estimated to be positive (warming effect), with a best estimate of $1.6 \mathrm{~W} \mathrm{\textrm {m } ^ { - 2 }}$ for 2005 (relative to 1750 pre-industrial values) (IPCC, 2008). The Intergovernmental Panel on Climate Change (IPCC) Fifth Assessment Report (AR5) estimates that the global mean temperature will increase by the late $21^{\text {st }}$ century $(2081-2100)$ relative to $1986-2005$, by $1^{\circ} \mathrm{C}$ to $3.7^{\circ} \mathrm{C}$ according to RCPs scenarios (IPCC, 2013).

Climate warming observed over the past several decades is associated with changes on hydrological and meteorological systems such as: changing precipitation patterns, intensity and extremes, melting of snow and ice, increasing atmospheric water vapour, increasing evaporation, and changes in soil moisture and runoff. Evapotranspiration (ET) represents the dominant consumer of water from catchments worldwide, accounted for about $62 \%$ of the precipitation (Dingman, 2015). Evapotranspiration is affected by climate change through many processes beginning with the increasing concentration of greenhouse gases, followed by their impacts on large scale circulation and changes to the global distribution of energy and moisture. Other factors that can might affect ET under a changing climate include changing land cover patterns and the $\mathrm{CO}_{2}$ fertilization effects that can limit the rate of plant transpiration under elevated levels of $\mathrm{CO}_{2}$ (Guo et al., 2017).

Estimation of reference evapotranspiration (ETo) is necessary for crop water requirements calculations and also in many of the rainfall-runoff and ecosystem models used in global change studies. Climate change impact studies are referred to emission scenarios (RCPs) and are usually based on projections of future climate from General Circulation Models (GCMs) and recently Earth System Models (ESMs) which are converted into reference evapotranspiration (ETo) using appropriate models. The assessment of ETo changes is critical in understanding the impacts of anthropogenic climate change on the sector of agriculture. Climate projections show increases in evapotranspiration over the $21^{\text {st }}$ century (IPCC, 2008; Koukouli et al., 2018b) because the evaporative demand, or 'reference evaporation', is projected to increase almost everywhere because the water-holding capacity of the atmosphere increases with higher temperatures, but 
relative humidity is not projected to change significantly. Carbon dioxide enrichment of the atmosphere has two potential competing implications for evapotranspiration from vegetation (IPCC, 2008). On the one hand, higher $\mathrm{CO}_{2}$ concentrations can reduce transpiration because the stomata of leaves need to open less in order to take up the same amount of $\mathrm{CO}_{2}$ for photosynthesis. Conversely, higher $\mathrm{CO}_{2}$ concentrations can increase plant growth, resulting in increased leaf area, and thus increased transpiration. The relative magnitudes of the above effects vary between plant types and in response to other influences. Changes in ET are affected by changes in precipitation and radiative forcing, and the changes would, in turn, impact on the water balance of runoff, soil moisture, water in reservoirs, the groundwater table and the salinization of shallow aquifers (IPCC, 2008).

The objective of this study was to investigate the effect of climate change on reference evapotranspiration in Agios Mamas area in Macedonia region (Northern Greece) for the middle (2041-2060) and the end (2081-2100) of the running century. For this purpose, data was derived from four ESMs: CanESM2 (Arora et al., 2011), GFDL-ESM2M (Dunne et al., 2013), HadGEM2-ES (Martin et al., 2011) and IPSL-CM5A-LR (Dufresne, 2013) under RCP2.6, RCP4.5 and RCP 8.5 climate change scenarios using as a baseline period 1981-2000. The selected models are the current generation of models used in IPCC AR5. The models' performance has shown a good capability in representing the observed behavior in past climate (IPCC, 2013). Although these models can be considered a sufficient tool for future projections, no individual model clearly emerges as 'the best' overall. For this reason, a number of models with different grid resolutions, was selected for increasing the reliability of the future projections. Based on the data taken from the climate models, the downscaling of daily climate variables was performed with the use of the weather generator ClimGen (Stöckle and Nelson, 1999) for the generation of synthetic time series which depict the future change of the climate variables. Future reference evapotranspiration was estimated using the FAO Penman-Monteith equation for all climate models. The annual ETo for the periods 2041-2060 and 2081-2100 was compared with the baseline period for the assessment of climate change impacts according to the different climate models used.

\section{Materials and methods}

\subsection{Study area and data}

The impact of climate change on reference evapotranspiration was studied in Agios Mamas area in the prefecture of Chalkidiki in Northern Greece which is located at $40^{\circ} 15^{\prime}$ latitude and $23^{\circ} 20^{\prime}$ longitude (Figure 1). The climate in the Prefecture of Chalkidiki is mainly Mediterranean, with hot summers and cool winters. The main use of the study area is agricultural and meteorological data that were used to generate the climate change scenarios were provided by station. Furthermore, the meteorological station of Agios Mamas is located in low altitude and, therefore, describes better the irrigation area. The time series data used in this study were precipitation $(\mathrm{mm})$, wind speed $\left(\mathrm{m} \mathrm{s}^{-1}\right)$, actual sunshine duration (hrs), mean temperature $\left({ }^{\circ} \mathrm{C}\right)$, and relative humidity (\%) for the baseline period 1981-2000 at daily time step.

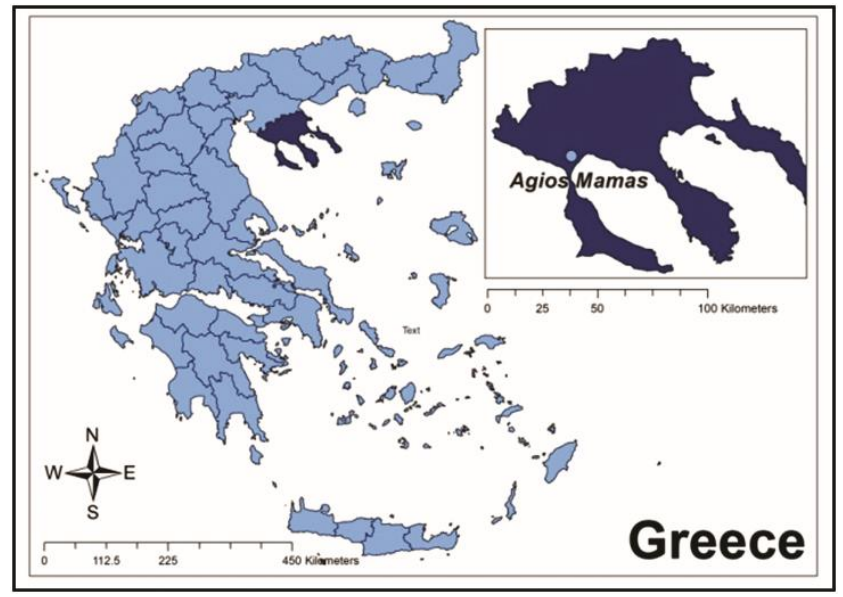

Figure 1. The location of Agios Mamas in Northern Greece

\subsection{RCP scenarios}

To investigate some of the most challenging questions about climate change confronting the global community, researchers develop and use emission scenarios. In climate research, emission scenarios are used as input to climate models to make projections of possible future climate change. Emission scenarios provide plausible descriptions of how the future may evolve with respect to a range of variables including socio-economic change, technological change, energy and land use and emissions of greenhouse gases and air pollutants (van Vuuren et al., 2011). The research community, motivated by the changing information needs of policy makers, has developed a new set of scenarios, Representative Concentration Pathways (RCPs) which are used in the IPCC Fifth Assessment Report (AR5) in preference to SRES scenarios (IPCC, 2000) used in previous IPCC Assessment Reports.

The newly developed RCPs are the product of an innovative collaboration between integrated assessment modelers, climate modelers, terrestrial ecosystem modelers and emission inventory experts. They include a set of four new pathways developed for long-term and near-term future projections and are internally consistent time-dependent forcing projections which take into account climate change mitigation policies to limit emissions (IPCC, 2013). The four RCPs together span the range of year 2100 radiative forcing values found in the open literature, from 2.6 to $8.5 \mathrm{~W} \mathrm{~m}^{-2}$ (van Vuuren et al., 2011) and are supplemented with extensions (Extended Concentration Pathways, ECPs), which allow climate modeling experiments through the year 2300. The numerical terms of RCPs scenarios is named after the approximate radiative forcing (RCP2.6, RCP4.5, RCP6 and RCP8.5) relative to the pre-industrial period achieved either in the year 2100 , or at stabilization after 2100 
(van Vuuren et al., 2011). They include one mitigation scenario leading to a very low forcing level (RCP2.6), two medium stabilization scenarios (RCP4.5 and RCP6) and one very high baseline emission scenario (RCP8.5) (van Vuuren et al., 2011). The RCP2.6 scenario assumes that annual GHG emissions peak at $3.0 \mathrm{~W} \mathrm{~m}^{-2}$ between 2010-2020 before declining to $2.6 \mathrm{~W} \mathrm{~m}^{-2}$ in 2100 , and requires strong mitigation of greenhouse gas concentrations in the $21^{\text {st }}$ century. Emissions in RCP4.5 peak around 2040 and stabilize after 2100 at $4.5 \mathrm{~W} \mathrm{~m}^{-2}$. In RCP6 emissions peak around 2080 and stabilize after 2100 at $6.0 \mathrm{~W} \mathrm{~m}^{-2}$. The RCP8.5 scenario is the closest to a 'business as usual' scenario of fossil fuel use, in which emissions continue to rise throughout the $21^{\text {st }}$ century.

According to the IPCC (2013) the atmospheric concentration of carbon dioxide $\left(\mathrm{CO}_{2}\right)$ in the year 2100 is predicted to reach $490 \mathrm{ppm}, 650 \mathrm{ppm}, 850 \mathrm{ppm}$ and 1370 for pathways RCP2.6, RCP4.5, RCP6 and RCP8.5, respectively. In this study, RCP2.6, RCP4.5 and RCP8.5 are used for the assessment of reference evapotranspiration under climate change.

\subsection{Climate models}

Climate models are the primary tools for scientists for investigating the response of the climate system to various forcings, for making climate predictions on seasonal to decadal time scales and for making projections of future climate over the coming century and beyond (IPCC, 2013). They are derived from fundamental physical laws (such as Newton's laws of motion), which are then subjected to physical approximations appropriate for the large-scale climate system, and then further approximated through mathematical discretization (Randall et al., 2007).

Climate models range from simple energy balance models to complex Earth System Models (ESMs) and have seen a number of improvements with developing improved physical process descriptions, introducing new model components and the improving model resolution. These models allow for policy-relevant calculations such as the carbon dioxide $\left(\mathrm{CO}_{2}\right)$ emissions compatible with a specified climate stabilization target (IPCC, 2013). Earth System Models (ESMs) are the current state-of-theart climate models which require state of the art highperformance computing and are the most comprehensive tools available for simulating past and future response of the climate system to external forcing, in which biogeochemical feedbacks play an important role (IPCC, 2013). ESMs expand on AOGCMs (Atmosphere-Ocean General Circulation Models) and include the representation of biogeochemical cycles such as those involved in the carbon cycle, the sulphur cycle, or ozone (Flato, 2011) and can even include the impact of human decision-making. Climate model simulations for the IPCC Fifth Assessment Report (AR5) are based on the fifth phase of the Coupled Model Intercomparison Project (CMIP5) which incorporates the latest versions of climate models, the Earth System Models, and focuses on the new scenarios RCPs.
In this study, CanESM2, GFDL-ESM2M, HadGEM2-ES and IPSL-CM5A-LR models under the newly developed RCPs were used for assessing climate change impact. CanESM2 is an Earth System Model developed at the Canadian Centre for Climate Modelling and Analysis (CCCma). It is composed of ocean, sea ice, atmosphere, land and carbon cycle models. The atmospheric component of CanESM2 uses the spectral transform method with T63 resolution in the horizontal (2.81 long $\times 2.79$ lat) and has 35 vertical levels (Arora et al., 2011). The ocean component has a horizontal resolution of $1.418 \times 0.948$ (long $\times$ lat) and there are 40 vertical levels with spacings which range from $10 \mathrm{~m}$ near the surface to nearly $400 \mathrm{~m}$ in the deep ocean (Yang and Saenko, 2012). GFDL-ESM2M is a global coupled climate-carbon Earth System Model developed at the National Oceanic and Atmospheric Administration (NOAA)/Geophysical Fluid Dynamics Laboratory (GFDL). The model, on land, includes a revised land model to simulate competitive vegetation distributions and functioning, including carbon cycling among vegetation, soil, and atmosphere and in the ocean, new biogeochemical algorithms including phytoplankton dynamics (Dunne et al., 2013). This model has an atmospheric horizontal resolution of $2.5 \times 2.0$ (long $\times$ lat) and its ocean component has a horizontal resolution of $1.0 \times 1.0$ (long $\times$ lat). The HadGEM2-ES of the Met Office Unified Model (MetUM) includes atmosphere, ocean and sea-ice components with and without a vertical extension in the atmosphere model to include a well-resolved stratosphere and an Earth-System (ES) component which includes dynamic vegetation, ocean biology and atmospheric chemistry (Martin et al., 2011). HadGEM2-ES has an atmospheric horizontal resolution of $1.875 \times 1.25$ (long $x$ lat) that equates to about $140 \mathrm{~km}$ at mid-latitudes. The ocean component has a horizontal resolution of $1.0 \mathrm{x}$ 1.0, with latitudinal resolution increasing smoothly from $30 \mathrm{~N} / \mathrm{S}$ to 0.33 at equator. The IPSL-CM5A model developed at Institute Pierre Simon Laplace (IPSL) is an Earth System Model (ESM). This model includes an interactive carbon cycle, a representation of tropospheric and stratospheric chemistry, and a comprehensive representation of aerosols (Dufresne, 2013). IPSL-CM5ALR is a low resolution version of IPSL-CM5A model with atmospheric horizontal resolution of $3.75 \times 1.89$ (long $x$ lat).

\subsection{Downscaling with weather generator-ClimGen}

While General Circulation Models (GCMs) are able to represent reasonably well the main features of the global distribution climate parameters (Lambert and Boer, 2001), they can't reproduce well the details of regional climate at temporal and spatial scales (Prudhomme et al., 2002; Xu, 1999 ) as their resolution is too coarse for many climate change impact studies. Therefore, there is a great need to develop downscaling methods which establish relationships between local weather variables and the large-scale ESMs' outputs for climate change impact assessment. Stochastic models that generate a suite of long series synthetic weather data from observed weather data have become important to address the inadequacy 
of short-term observed weather data, for analysis of agricultural, hydrological, environmental and other weather-driven systems (Georgiou and Papamichail, 2008; Richardson, 1985). Stochastic weather generators are statistical models used to produce synthetic weather time series, which are expected to be statistically similar to the observed weather time series for a location of interest (Georgiou and Karpouzos, 2017; Koukouli and Georgiou, 2018; Koukouli et al., 2018a). They are usually combined with hydrological and environmental models for water resources and environmental management and more often as downscaling tools to produce high-resolution climate change projections by linking their parameters to climate model outputs (Chen and Brissete, 2014). The weather generators compared to other statistical downscaling methods have the advantage of producing an ensemble of equiprobable realizations of climate change projections for analyzing risk-based environmental impacts (Chen and Brissete, 2014).

ClimGen (Stöckle and Nelson, 1999) is a daily time step stochastic model that generates daily precipitation $(\mathrm{mm})$, maximum and minimum temperature $\left({ }^{\circ} \mathrm{C}\right)$, solar radiation

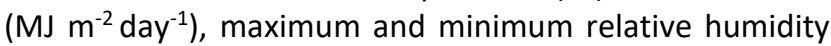
(\%) and wind speed $\left(\mathrm{m} \mathrm{s}^{-1}\right)$ data series which preserve the statistical characteristics of the historical weather data. The model requires inputs of daily series of these weather variables to calculate the parameters used in the generation process for any length of period at a location of interest. ClimGen has produced promising results for the generation of weather data for various climatic conditions (Stöckle and Nelson, 1999). The model has the capability to automate the task of parameterizing the historical weather data. Also, the use of a Weibull distribution to represent daily precipitation amounts in ClimGen is superior to other probability distribution functions (Selker and Haith, 1990). Additionally, the spline approach is an improvement over the one-term Fourier series used by many other weather generators to model seasonal variations in climate data (McKague et al., 2005). For sites where measured daily solar radiation data are not available, ClimGen provides an option to estimate solar radiation using a temperature-based approach (Bristow and Campbell, 1984).

\subsection{Estimation of reference evapotranspiration}

Reference evapotranspiration (ETo) is the evapotranspiration from a crop with specific characteristics and which is not short of water (McMahon et al., 2013). According to FAO (Allen et al., 1998), ETo is defined as follows "the evapotranspiration from a hypothetical grass reference crop with an assumed crop height of $0.12 \mathrm{~m}$, a fixed surface resistance of $70 \mathrm{~s} \mathrm{~m}^{-1}$ and an albedo of 0.23, closely resembling an extensive surface of green, well-watered grass of uniform height, actively growing and completely shading the ground". Given the likelihood of future change in the global hydrological cycle, there is a need to understand the response of ETo to climate change (Kingston, 2009).

Climate change is projected to result in an intensification of the hydrological cycle but there is substantial uncertainty in how this will impact freshwater availability. A relatively overlooked aspect of this uncertainty pertains to how different methods of estimating reference evapotranspiration $\left(E T_{0}\right)$ respond to changing climate (Kingston et al., 2009). Therefore, clear understanding of $E T_{0}$ dynamics is vital for the assessment of impacts of future climate change on water and subsequent implications for the agricultural sector. Reference evapotranspiration is an important index of hydrologic budgets at different spatial scales and represents a critical variable for understanding regional biological processes and irrigation design (Lu, 2005).

Among the methods available to estimate $E T_{0}$, the Food and Agricultural Organisation of the United Nations (FAO) recommends the use of the Penman-Monteith equation (Allen et al., 1998) which is known as FAO PenmanMonteith method, as it directly incorporates the relevant meteorological variables which control evapotranspiration. It is often referred to as a combinational method, as it combines the energy balance and mass transfer components of evapotranspiration, and takes into account vegetation-dependent processes such as aerodynamic and surface resistances (Guo et al., 2017). The FAO Penman-Monteith equation is based on temperature, net radiation, wind speed and relative humidity and is described as follows (Allen et al., 1998):

$$
\mathrm{ET}_{\mathrm{o}}=\frac{0.408 \times \Delta \times\left(\mathrm{R}_{\mathrm{n}}-\mathrm{G}\right)+\nu \times \frac{900}{\mathrm{~T}_{\text {mean }}+273} \times \mathrm{u}_{2} \times\left(\mathrm{e}_{\mathrm{s}}-\mathrm{e}_{\mathrm{a}}\right)}{\Delta+\nu \times\left(1+0.34 \times \mathrm{u}_{2}\right)}
$$

where ETo is the reference evapotranspiration, $(\mathrm{mm}$ day $\left.^{-1}\right), R_{n}$ is the net radiation $\left(M J m^{-2}\right.$ day $\left.^{-1}\right), G$ is the soil

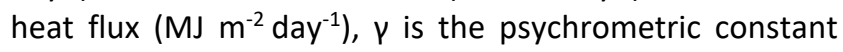
$\left(\mathrm{kPa}{ }^{\circ} \mathrm{C}^{-1}\right), \mathrm{e}_{\mathrm{s}}$ is the saturation vapour pressure $(\mathrm{kPa}), \mathrm{e}_{\mathrm{a}}$ is the actual vapour pressure $(\mathrm{kPa}), \Delta$ is the slope of the saturation vapour pressure - temperature curve $\left(\mathrm{kPa}{ }^{\circ} \mathrm{C}^{-1}\right)$, $\mathrm{T}_{\text {mean }}$ is the mean daily air temperature $\left({ }^{\circ} \mathrm{C}\right)$ and $\mathrm{u}_{2}$ is the

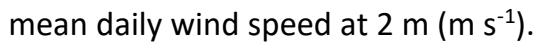

\section{Results and discussion}

This study was focused on the impact of climate change on the reference evapotranspiration (ETo) of Agios Mamas in Northern Greece. For this purpose, weather data from CanESM2, GFDL-ESM2M, HadGEM2-ES and IPSL-CM5A-LR Earth System Models under the climate change scenarios RCP2.6, RCP4.5 and RCP8.5 were used for the climate change periods 2041-2060 and 2081-2100 and for the baseline period (1981-2000).

Based on the data derived from the four climate models, the downscaling of a 20-year data set (1981-2000) of daily climate variables including precipitation $(\mathrm{Pr})$, maximum and minimum temperature $\left(T_{\max }, T_{\min }\right)$, solar radiation $\left(R_{s}\right)$, maximum and minimum relative humidity $\left(\mathrm{RH}_{\max }, \mathrm{RH}_{\min }\right)$, and wind speed $\left(u_{2}\right)$ performed using the weather generator ClimGen for the generation of synthetic time series which depict the future change of the climate variables. The change between the baseline period and the periods of climate change 2041-2060 and 2081-2100 was calculated for the different climate variables. According to that change, the historic data series of the 
study area was perturbed. The perturbed time series then was used by ClimGen for the generation of an ensemble of synthetic time series of the weather variables which preserve the statistic characteristics of the historic time series. The generated and observed weather data series were compared in order to confirm the statistical consistency. Finally, this ensemble of synthetic time series of climate variables was used for the estimation of an ensemble of reference evapotranspiration time series of the study area.

First the change in temperature is analyzed since it is a critical variable for the estimation of evapotranspiration. In Table 1, the mean annual temperature of Agios Mamas under RCP2.6, RCP4.5 and RCP8.5 based on CanESM2, GFDL-ESM2M, HadGEM2-ES and IPSL-CM5A-LR models, for the periods of climate change 2041-2060 and 2081-2100 and for the baseline period 1981-2000, are presented. The models' projections indicate that mean annual temperature will increase by the middle and the end of the $21^{\text {st }}$ century compared to the baseline period. The greatest rise in temperature is observed under the high emission scenario RCP8.5, the lowest under the low emission scenario RCP2.6 while the medium emission scenario RCP4.5 shows moderate values of increase. Among the climate models, GFDL-ESM2M projects the lowest increase whereas HadGEM2-ES gives the highest increase. The observed changes in annual temperature will be higher for the climate change period 2081-2100 compared to 2041-2060 under RCP4.5 and RCP8.5 (except GFDL-ESM2M for RCP4.5) with the latest scenario having greater values of rise between the two periods. The above can be attributed to the fact that RCP4.5 is a moderate stabilization scenario in which emissions peak around 2040 and stabilize after 2100 while in RCP8.5 emissions continue to rise throughout the $21^{\text {st }}$ century. As regards to RCP2.6 the differences in temperature change between the middle and the end of the $21^{\text {st }}$ century will be slighter with HadGEM2-ES and IPSL-CM5A-LR models showing greater increase during 2041-2060 compared to 2081-2100. The slighter differences in temperature change between the two periods under RCP2.6 are due to the low emissions that peak between 2010-2020 before declining in 2100 .

Table 1. Differences in mean annual temperature $\left({ }^{\circ} \mathrm{C}\right)$ of Agios Mamas according to CanESM2, GFDL-ESM2M, HadGEM2-ES and IPSLCM5A-LR under RCP2.6, RCP4.5 and RCP8.5 during 2041-2060 and 2081-2100 in relation to 1981-2000

\begin{tabular}{|c|c|c|c|c|c|c|c|}
\hline \multicolumn{8}{|c|}{ Mean Annual Temperature $\left({ }^{\circ} \mathrm{C}\right)$} \\
\hline \multirow{2}{*}{$\begin{array}{l}\text { Historical Time Series } \\
\text { (Ag. Mamas) 1981-2000 }\end{array}$} & \multirow[b]{2}{*}{ Climate Models } & \multicolumn{2}{|c|}{ RCP2.6 } & \multicolumn{2}{|c|}{ RCP4.5 } & \multicolumn{2}{|c|}{ RCP8.5 } \\
\hline & & 2041-2060 & 2081-2100 & 2041-2060 & 2081-2100 & 2041-2060 & 2081-2100 \\
\hline \multirow{8}{*}{$\begin{array}{l}14.42 \\
\Delta T_{\text {mean }}\end{array}$} & \multirow{2}{*}{ CanESM2 } & 16.51 & 16.55 & 16.97 & 17.47 & 17.38 & 20.42 \\
\hline & & 2.09 & 2.13 & 2.54 & 3.05 & 2.96 & 6.00 \\
\hline & \multirow{2}{*}{ GFDL-ESM2M } & 15.09 & 15.30 & 15.68 & 15.52 & 16.06 & 17.58 \\
\hline & & 0.67 & 0.88 & 1.26 & 1.10 & 1.64 & 3.16 \\
\hline & \multirow{2}{*}{ HadGEM2-ES } & 17.02 & 16.93 & 17.08 & 18.27 & 17.75 & 20.97 \\
\hline & & 2.60 & 2.51 & 2.66 & 3.85 & 3.33 & 6.55 \\
\hline & \multirow{2}{*}{ IPSL-CM5A-LR } & 16.72 & 16.31 & 16.76 & 17.80 & 17.66 & 21.03 \\
\hline & & 2.30 & 1.89 & 2.34 & 3.38 & 3.24 & 6.61 \\
\hline
\end{tabular}

The mitigation scenario $\mathrm{RCP} 2.6$ projects a rise in mean annual temperature ranging from $0.67^{\circ} \mathrm{C}$ to $2.60^{\circ} \mathrm{C}$ during 2041-2060 and from $0.88^{\circ} \mathrm{C}$ to $2.51^{\circ} \mathrm{C}$ during $2081-2100$, according to ESMs GFDL-ESM2M and HadGEM2-ES, respectively. The predicted increases under the medium stabilization scenario RCP4.5 will be by $1.26^{\circ} \mathrm{C}$ (GFDL$\mathrm{ESM} 2 \mathrm{M}$ ) to $2.66^{\circ} \mathrm{C}$ (HadGEM2-ES) and $1.10^{\circ} \mathrm{C}$ (GFDL$\mathrm{ESM} 2 \mathrm{M}$ ) to $3.85^{\circ} \mathrm{C}$ (HadGEM2-ES) for the periods 20412060 and 2081-2100, respectively. According to the high emission scenario RCP8.5, mean annual temperature is projected to increase by $1.64^{\circ} \mathrm{C}$ (GFDL-ESM2M) to $3.33^{\circ} \mathrm{C}$ (HadGEM2-ES) for the climate change period 2041-2060 and by $3.16^{\circ} \mathrm{C}$ (GFDL-ESM2M) to $6.61^{\circ} \mathrm{C}$ (IPSL-CM5A-LR) for 2081-2100 compared to the baseline period 1981-2000.

The results in the current study are presented with the use of heatmaps which reveal the variability in sequential time-steps (years) and box plots that depict the variability of the statistical pattern of parameters under climate change. Heatmaps are the representation of data in the form of a map in which data values are represented as colours. The heatmaps shown in Figure 2 represent the varying temperature changes during the periods of climate change a) 2041-2060 and b) 2081-2100 according to RCP2.6, RCP4.5 and RCP8.5 projected by the climate models. The below heatmap consists of a colour pattern (red: higher values of increase and blue: lower values) and the colour bar depicts the gradual transitions between the above two boundary levels. The scale in Figure $2 b$ is greater (about $1^{\circ} \mathrm{C}-6.5^{\circ} \mathrm{C}$ ) compared to Figure 2a (about $1^{\circ} \mathrm{C}-3.5^{\circ} \mathrm{C}$ ) indicating the greater temperature rise during the end of the century in relation to the middle of the century. As regards to GFDL-ESM2M model, temperature change is represented only by gradients of blue colour showing that the above model has the lowest values of temperature increase. By the interpretation of the heatmaps, it can be noticed that for all climate models, the blue gradient fades, the red becomes darker or blue changes to red shades among the three RCPs indicating that the temperature change increases from the low 
emission scenario RCP2.6 to the high emission scenario RCP8.5.

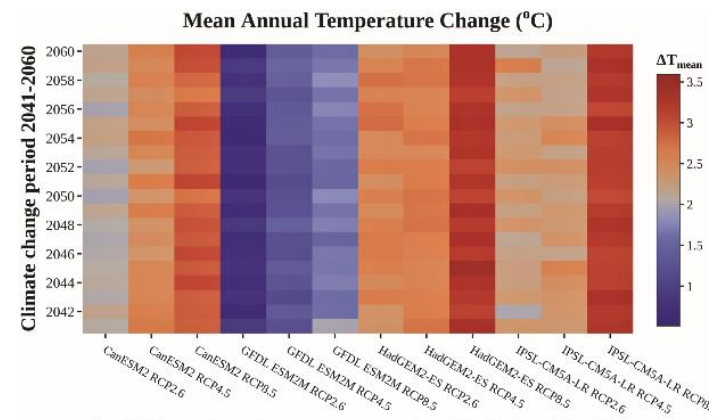

a) Climate change period 2041-2060

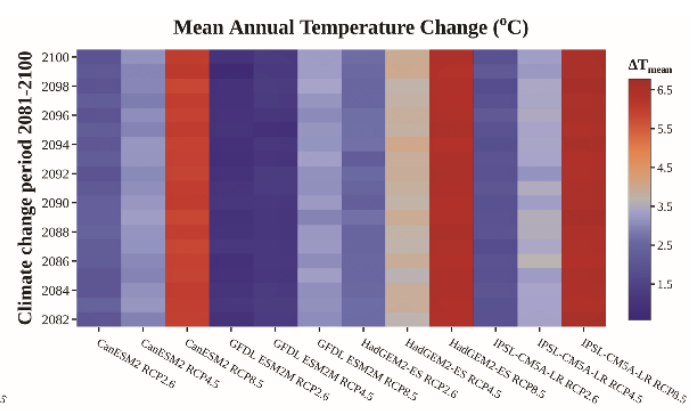

b) Climate change period 2081-2100

Figure 2. Heatmaps of mean annual temperature change $\left({ }^{\circ} \mathrm{C}\right)$ of Agios Mamas according to CanESM2, GFDL-ESM2M, HadGEM2ES and IPSL-CM5A-LR under RCP2.6, RCP4.5 and RCP8.5 during a) 2041-2060 and b) 2081-2100 relative to $1981-2000$

Box plots of mean temperature change $\left({ }^{\circ} \mathrm{C}\right)$ under RCP2.6, RCP4.5 and RCP8.5 projected by the four different climate models are shown in Figure 3 . The midline within each box plot represents the median values and lower and upper lines give the $25^{\text {th }}$ percentile and $75^{\text {th }}$ percentile value. The whiskers at the top and bottom of the box plots represent the maximum and minimum observed values, respectively. The increase in mean annual temperature, projected by the four ESMs is obvious according to the box plots with RCP8.5 having the greatest maximum and mean value among the climate scenarios under each climate model for both periods. It can be noticed that medians are generally close to the mean and the box plots of each data set are comparatively short suggesting a high level of agreement. The largest spread in distribution of the mean temperature is observed under the medium emission scenario RCP4.5 for the majority of the cases during both climate change periods. The lowest maximum and mean value is observed according to GFDL-ESM2M while the highest under HadGEM2-ES for both the middle and the end of the century.

Table 2 shows the differences in mean annual solar radiation (MJ $\mathrm{m}^{-2}$ day $^{-1}$ ) projected by CanESM2, GFDL-ESM2M, HadGEM2-ES and IPSL-CM5A-LR according to scenarios RCP2.6, RCP4.5 and RCP8.5 during 2041-2060 and 2081-2100 in relation to the baseline period. The models' simulations show an increase in mean annual solar radiation under the three climate change scenarios RCPs for both periods compared to 1981-2000. It is observed that the increase in mean solar radiation during the period 2081-2100 will be greater compared to 2041-2060 according to the climate models under the RCPs with the exceptions of RCP4.5 during 2081-2100 projected by GFDL-ESM2M and IPSL-CM5A-LR.

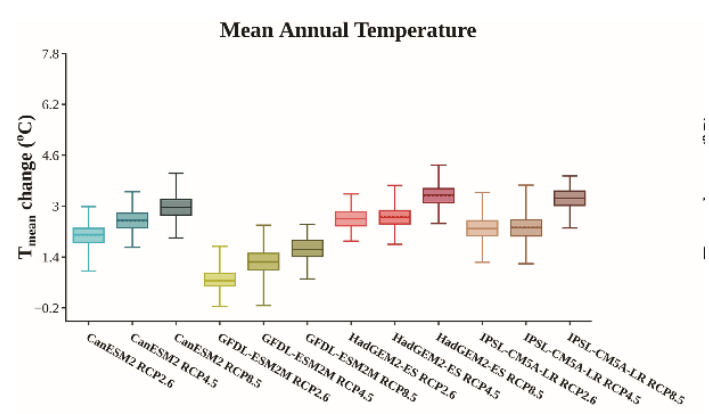

a) Climate change period 2041-2060

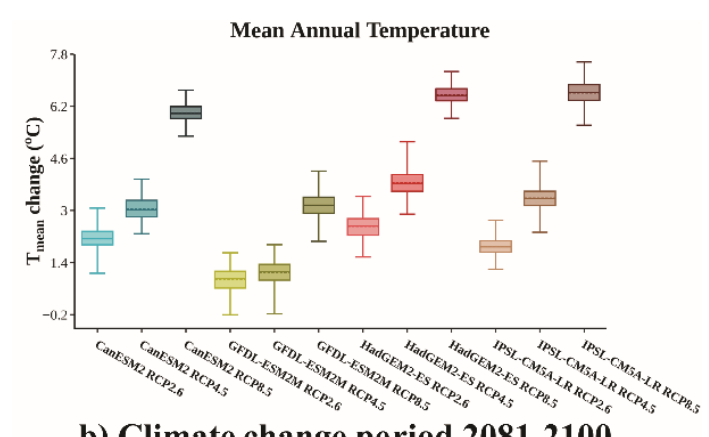

b) Climate change period 2081-2100

Figure 3. Box plots of mean annual temperature change $\left({ }^{\circ} \mathrm{C}\right)$ of Agios Mamas according to CanESM2, GFDL-ESM2M, HadGEM2ES and IPSL-CM5A-LR under RCP2.6, RCP4.5 and RCP8.5 during a) 2041-2060 and b) 2081-2100 relative to $1981-2000$

CanESM2 projects a rise in mean annual solar radiation ranging from $0.16 \mathrm{MJ} \mathrm{m}^{-2}$ day $^{-1}$ under RCP4.5 during 2041-2060 to $0.85 \mathrm{MJ} \mathrm{m}^{-2}$ day $^{-1}$ according to RCP8.5 for 2081-2100. As regards to GFDL-ESM2M the rise is by $0.25 \mathrm{MJ} \mathrm{m}^{-2}$ day $^{-1}$ to $0.95 \mathrm{MJ} \mathrm{m}^{-2}$ day $^{-1}$ under RCP4.5 and RCP8.5, respectively for 2081-2100. Climate model HadGEM2-ES predicts a rise that ranges from $1.33 \mathrm{MJ} \mathrm{m}^{-2}$ day $^{-1}$ (RCP4.5 for 2041-2060) to $2.13 \mathrm{MJ} \mathrm{m}^{-2}$ day $^{-1}$ (RCP8.5 for 2081-2100). The increase in solar radiation projected by IPSL-CM5A-LR is from $0.73 \mathrm{MJ} \mathrm{m}^{-2}$ day $^{-1}$ to $1.30 \mathrm{MJ} \mathrm{m}^{-2}$ day $^{-1}$ during 2081-2100 according to RCP4.5 and RCP2.6, respectively. Among the climate models used, HadGEM2ES projects the highest increase in solar radiation for both the middle and the end of the century under the three RCPs.

Heatmaps of mean solar radiation change ( $\mathrm{MJ} \mathrm{\textrm {m } ^ { - 2 }}$ day $^{-1}$ ) under RCP2.6, RCP4.5 and RCP8.5 projected by the four different ESMs are shown in Figure 4. According to the heatmaps, the greatest values are identified for HadGEM2-ES model (shades of red colour) during both climate change periods indicating the highest increase in solar radiation among the models used. The scale for the end of the century reaches greater values in relation to the middle of the century showing the greater solar radiation increase during 2081-2100. The interpretation of the visualization of the data of solar radiation does not show a specific pattern of increase among the three RCPs. 
Table 2. Differences in mean annual solar radiation (MJ $\mathrm{m}^{-2}$ day ${ }^{-1}$ ) of Agios Mamas according to CanESM2, GFDL-ESM2M, HadGEM2-ES and IPSL-CM5A-LR under RCP2.6, RCP4.5 and RCP8.5 during 2041-2060 and 2081-2100 in relation to 1981-2000

\begin{tabular}{|c|c|c|c|c|c|c|c|}
\hline \multicolumn{8}{|c|}{ Mean Annual Solar Radiation (MJ $\mathrm{m}^{-2}$ day $^{-1}$ ) } \\
\hline \multirow{2}{*}{$\begin{array}{c}\text { Historical Time } \\
\text { Series (Ag. Mamas) } \\
\text { 1981-2000 }\end{array}$} & \multirow[b]{2}{*}{ Climate Models } & \multicolumn{2}{|c|}{ RCP2.6 } & \multicolumn{2}{|c|}{ RCP4.5 } & \multicolumn{2}{|c|}{ RCP8.5 } \\
\hline & & 2041-2060 & 2081-2100 & 2041-2060 & 2081-2100 & 2041-2060 & 2081-2100 \\
\hline \multirow{8}{*}{$\begin{array}{c}12.66 \\
\Delta R_{s}\end{array}$} & \multirow{2}{*}{ CanESM2 } & 13.08 & 13.31 & 12.82 & 12.93 & 13.34 & 13.51 \\
\hline & & 0.42 & 0.65 & 0.16 & 0.28 & 0.68 & 0.85 \\
\hline & \multirow{2}{*}{ GFDL-ESM2M } & 13.06 & 13.37 & 13.18 & 12.91 & 12.93 & 13.61 \\
\hline & & 0.41 & 0.71 & 0.52 & 0.25 & 0.28 & 0.95 \\
\hline & \multirow{2}{*}{ HadGEM2-ES } & 14.16 & 14.18 & 13.99 & 14.30 & 14.15 & 14.79 \\
\hline & & 1.50 & 1.52 & 1.33 & 1.64 & 1.49 & 2.13 \\
\hline & \multirow{2}{*}{ IPSL-CM5A-LR } & 13.75 & 13.96 & 13.52 & 13.39 & 13.77 & 13.86 \\
\hline & & 1.09 & 1.30 & 0.86 & 0.73 & 1.12 & 1.20 \\
\hline
\end{tabular}

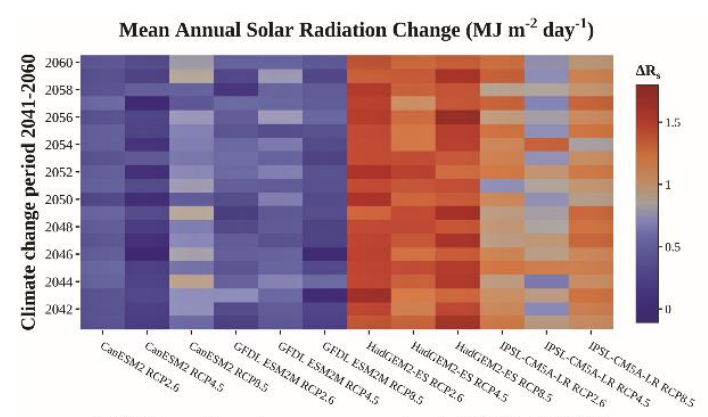

a) Climate change period 2041-2060

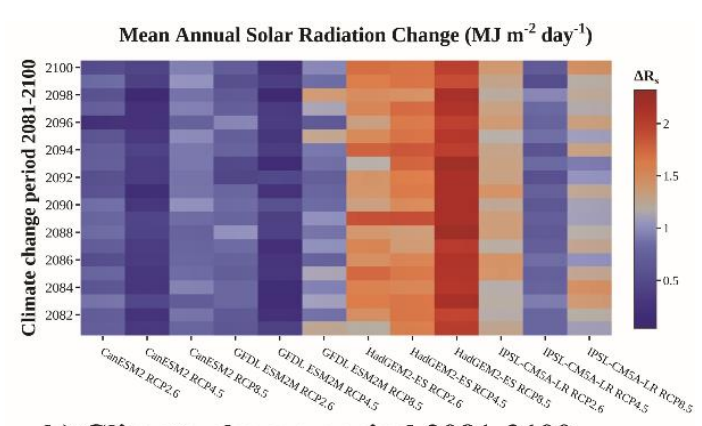

b) Climate change period 2081-2100

Figure 4. Heatmaps of mean annual solar radiation change (MJ $\mathrm{m}^{-2}$ day $^{-1}$ ) of Agios Mamas according to CanESM2, GFDLESM2M, HadGEM2-ES and IPSL-CM5A-LR under RCP2.6, RCP4.5 and RCP8.5 during a) 2041-2060 and b) 2081-2100 relative to 1981-2000

Box plots of mean annual solar radiation change $\left(\mathrm{MJ} \mathrm{m}^{-2}\right.$ day $^{-1}$ ) under RCP2.6, RCP4.5 and RCP8.5 projected by the four different climate models are shown in Figure 5 . The heights of the rectangle of the box plots are different and the spread of each data set is different indicating great variation. Among the four models, HadGEM2-ES shows the greatest maximum and mean value during each climate change period, indicating that the above model gives the highest increase in annual solar radiation.

In Table 3, the mean annual reference evapotranspiration of the study area under RCP2.6, RCP4.5 and RCP8.5 projected by the climate models CanESM2, GFDL-ESM2M, HadGEM2-ES and IPSL-CM5A-LR for the periods of climate change 2041-2060 and 2081-2100 and for the baseline period (1981-2000), are depicted. It can be noted that all climate models predict an increase in mean annual reference evapotranspiration for the middle and the end of the century compared to the historical period. Generally, the projected increase is greater during 2081-2100 in relation to 2041-2060 with a few exceptions.

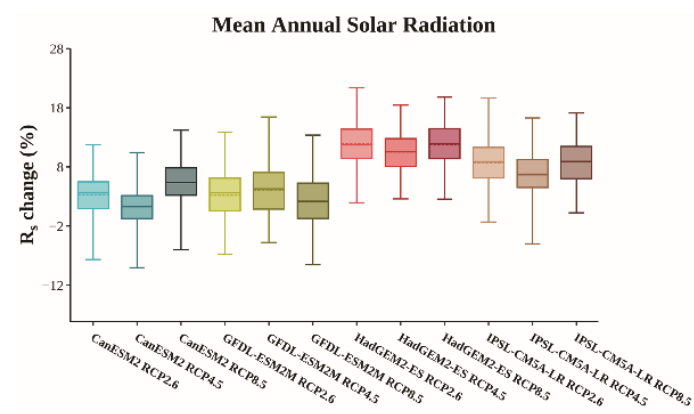

a) Climate change period 2041-2060

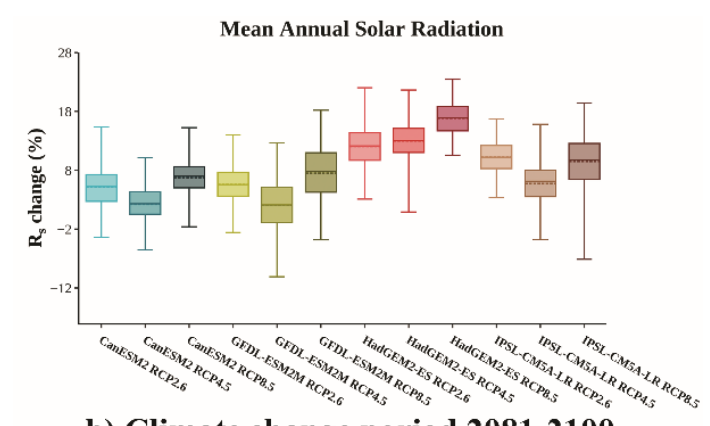

b) Climate change period 2081-2100

Figure 5. Box plots of mean annual solar radiation change (MJ m-2 day $^{-1}$ ) of Agios Mamas according to CanESM2, GFDLESM2M, HadGEM2-ES and IPSL-CM5A-LR under RCP2.6, RCP4.5 and RCP8.5 during a) 2041-2060 and b) 2081-2100 relative to 1981-2000

The high emission scenario RCP8.5 projects a greater increase in mean annual evapotranspiration for both climate change periods in relation to RCP2.6 and RCP4.5 scenarios. The highest values of increase in annual $E T_{0}$ are estimated during 2081-2100 under RCP8.5 by $296 \mathrm{~mm}$ (CanESM2), 140 mm (GFDL-ESM2M), 408 mm (HadGEM2ES) and $234 \mathrm{~mm}$ (IPSL-CM5A-LR). Regarding 2041-2060 according to RCP8.5, CanESM2 projects a rise in annual 
ET。 by $211 \mathrm{~mm}$, GFDL-ESM2M $64 \mathrm{~mm}$, HadGEM2-ES 239 $\mathrm{mm}$ and IPSL-CM5A-LR $201 \mathrm{~mm}$. Between the models used, HadGEM2-ES gives the highest values of increase in annual ETo while GFDL-ESM2M predicts the lowest increase under the different RCPs for both periods of climate change.

Table 3. Differences in mean annual reference evapotranspiration $(\mathrm{mm})$ of Agios Mamas according to CanESM2, GFDL-ESM2M, HadGEM2-ES and IPSL-CM5A-LR under RCP2.6, RCP4.5 and RCP8.5 during 2041-2060 and 2081-2100 in relation to $1981-2000$

\begin{tabular}{|c|c|c|c|c|c|c|c|}
\hline \multicolumn{8}{|c|}{ Mean Annual Reference Evapotranspiration (mm) } \\
\hline \multirow{2}{*}{$\begin{array}{l}\text { Historical Time Series } \\
\text { (Ag. Mamas) 1981-2000 }\end{array}$} & \multirow{2}{*}{ Climate Models } & \multicolumn{2}{|c|}{ RCP2.6 } & \multicolumn{2}{|c|}{ RCP4.5 } & \multicolumn{2}{|c|}{ RCP8.5 } \\
\hline & & 2041-2060 & 2081-2100 & 2041-2060 & 2081-2100 & 2041-2060 & 2081-2100 \\
\hline \multirow{12}{*}{$\begin{array}{c}1066 \\
\Delta \mathrm{ET}_{\mathrm{o}} \%\end{array}$} & \multirow{3}{*}{ CanESM2 } & 1236 & 1243 & 1248 & 1246 & 1277 & 1362 \\
\hline & & 170 & 177 & 182 & 180 & 211 & 296 \\
\hline & & 16.0 & 16.6 & 17.1 & 16.9 & 19.8 & 27.8 \\
\hline & \multirow{3}{*}{ GFDL-ESM2M } & 1108 & 1200 & 1132 & 1126 & 1130 & 1205 \\
\hline & & 42 & 134 & 66 & 60 & 64 & 140 \\
\hline & & 4.0 & 12.6 & 6.2 & 5.6 & 6.0 & 13.1 \\
\hline & \multirow{3}{*}{ HadGEM2-ES } & 1279 & 1272 & 1288 & 1330 & 1305 & 1474 \\
\hline & & 213 & 207 & 222 & 264 & 239 & 408 \\
\hline & & 20.0 & 19.4 & 20.8 & 24.8 & 22.5 & 38.3 \\
\hline & \multirow{3}{*}{ IPSL-CM5A-LR } & 1188 & 1219 & 1237 & 1262 & 1267 & 1300 \\
\hline & & 122 & 153 & 171 & 196 & 201 & 234 \\
\hline & & 11.5 & 14.3 & 16.1 & 18.4 & 18.9 & 21.9 \\
\hline
\end{tabular}

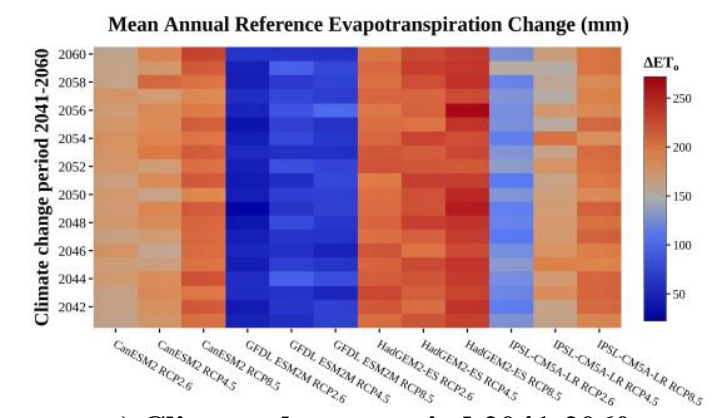

a) Climate change period 2041-2060

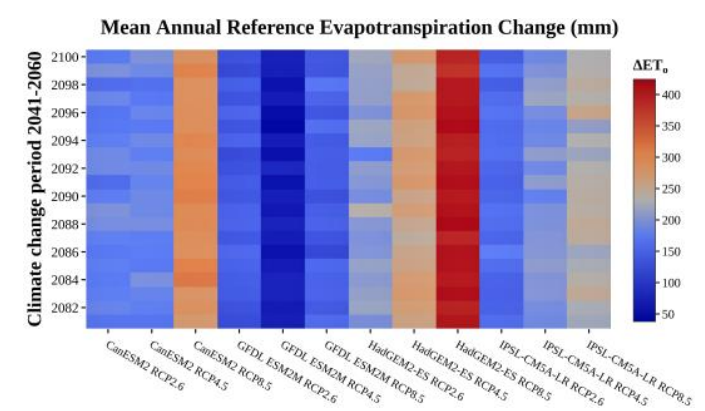

b) Climate change period 2081-2100

Figure 6. Heatmaps of mean annual reference evapotranspiration change $(\mathrm{mm})$ of Agios Mamas according to CanESM2, GFDL-ESM2M, HadGEM2-ES and IPSL-CM5A-LR under RCP2.6, RCP4.5 and RCP8.5 during a) 2041-2060 and b) 2081-2100 relative to $1981-2000$

In Figure 6 the varying reference evapotranspiration change during the periods of climate change a) 2041-2060 and b) 2081-2100 according to RCP2.6, RCP4.5 and RCP8.5 projected by CanESM2, GFDL-ESM2M, HadGEM2-ES and IPSL-CM5A-LR models, is depicted. It can be noticed that in each column the colour gradient does not become darker through the years, indicating that reference evapotranspiration does not increase with the years in each climate change period but the mean reference evapotranspiration increases in the climate change period. The scale regarding 2081-2100 reaches the value $400 \mathrm{~mm}$ whereas for 2041-2060, it reaches about $250 \mathrm{~mm}$ meaning that the rise is greater by the end of the century in relation to the middle of the century. For both periods, reference evapotranspiration change according to GFDLESM2M model is represented by darker shades of blue among the models used, indicating the lowest increase. The column with the darkest red shade among all the columns, is referred to HadGEM2-ES under the high emission scenario RCP8.5 during 2081-2100, implying the greatest increase in reference evapotranspiration.

In Figure 7 the box plots of annual reference evapotranspiration change (\%) for the climate change periods in relation to the baseline period based on the four climate models are presented. The box plots of each data set are comparatively short showing a high level of agreement. Additionally, medians are generally close to the mean and the median of each box plot is comparatively in the middle of the rectangle. According to the box plots analysis it can be noted that the whiskers are about the same length for the majority of the box plots but the spread of the data sets is different. The greatest mean and maximum values are observed under HadGEM2-ES whereas the lowest under GFDL-ESM2M model for both periods indicating the highest and lowest increase in reference evapotranspiration among the ESMs, respectively. According to the box plots, during 2081-2100 the high emission scenario RCP8.5 has the greatest maximum and mean value for the four climate models used. 


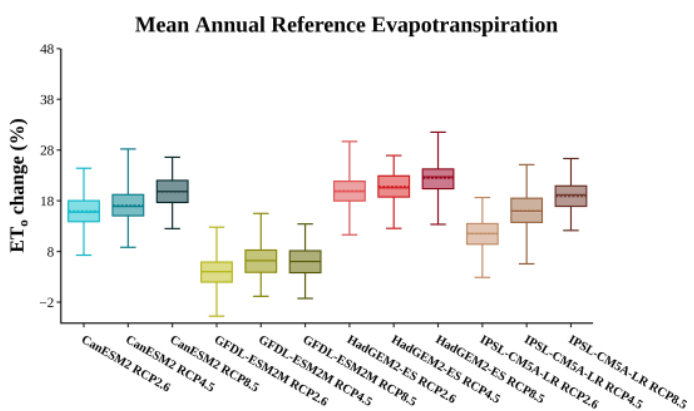

a) Climate change period 2041-2060

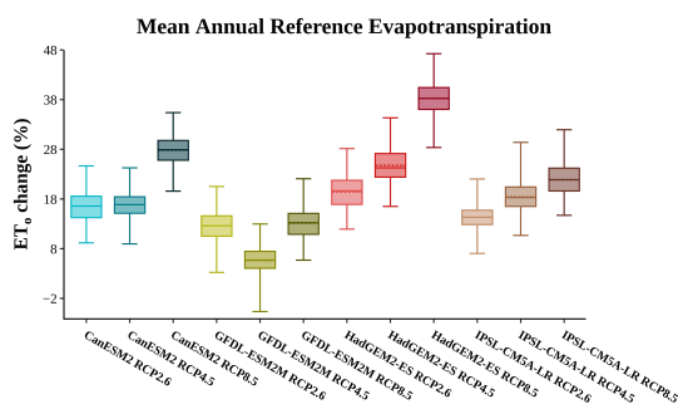

b) Climate change period 2081-2100

Figure 7. Box plots of mean annual reference evapotranspiration change $(\mathrm{mm})$ of Agios Mamas according to CanESM2, GFDLESM2M, HadGEM2-ES and IPSL-CM5A-LR under RCP2.6, RCP4.5 and RCP8.5 during a) 2041-2060 and b) 2081-2100 relative to 1981-2000

The box plots of reference evapotranspiration change (Figure 7) have similar pattern with those of temperature change (Figure 2) for both the middle and the end of the $21^{\text {st }}$ century. As regards to solar radiation, the box plots have differences in their pattern compared to reference evapotranspiration. The above confirm that the rise in reference evapotranspiration due to climate change is driven mainly by the increase of temperature in the future and secondly by solar radiation rise. With higher temperatures, the water-holding capacity of the atmosphere increases resulting in reference evaporation increase. Additionally, $\mathrm{CO}_{2}$ enrichment of the atmosphere can increase plant growth, resulting in increased leaf area, and thus increased transpiration. There were differences in future projections of temperature, solar radiation and ETo among the selected climate models, which seem to not be related only with the model resolution. Thus, a number of models with different spatial and meteorological characteristics should be used for increasing the reliability of the results.

\section{Conclusions}

In this study, the effects of climate change on the reference evapotranspiration (ETo) of Agios Mamas in Northern Greece for the middle (2041-2060) and the end of the $21^{\text {st }}$ century (2081-2100), were assessed. The climate change projections were done according to CanESM2, GFDL-ESM2M, HadGEM2-ES and IPSL-CM5A-LR
Earth System Models under RCP2.6, RCP4.5 and RCP8.5 climate change scenarios. The results suggested that mean annual temperature and solar radiation are projected to increase in 2041-2060 and 2081-2100 compared to 1981-2000 with the greatest increase recorded for the end of the century. The greatest rise in annual temperature by $6.61^{\circ} \mathrm{C}$ is observed under the high emission scenario RCP8.5 according to IPSL-CM5A-LR for the climate change period 2081-2100. The greatest rise in solar radiation is predicted under RCP8.5 for the end of the century (2081-2100) according to HadGEM2-ES reaching to an increase by $2.13 \mathrm{MJ} \mathrm{m}^{-2} \mathrm{day}^{-1}$. The rise in mean annual temperature and solar radiation will, in turn impact on mean annual reference evapotranspiration with the greatest increase of $408 \mathrm{~mm}$ predicted by HadGEM2ES model under RCP8.5 during the end of the century (2081-2100). The reference evapotranspiration increase has similar pattern with the temperature rise indicating that future changes in evapotranspiration due to climate change are driven mainly by temperature changes and secondly by solar radiation. There were differences in temperature, solar radiation and reference evapotranspiration increase among the four climate models showing great variation for the ensemble synthetic time series with HadGEM2-ES giving the highest values of increase. GFDL-ESM2M projects the lowest increase in temperature and reference evapotranspiration. The above indicates that the use of a number of climate models is required in climate change studies for increasing the reliability of the future projections. The changes in reference evapotranspiration in response to the future climate change may have significant impacts on the agricultural sector. Therefore, the estimation of reference evapotranspiration in a climate change framework is a critical factor in the design of adaptation strategies regarding irrigation systems planning and agricultural water management.

\section{References}

Allen R.G., Pereira L.S., Raes D. and Smith M. (1998), Crop evapotranspiration guidelines for computing crop water requirements, FAO Irrigation and Drainage Paper, No. 56, Rome, Italy.

Arora V.K., Scinocca J.F., Boer G.J., Christian J.R., Denman K.L., Flato G.M., Kharin V.V., Lee W.G. and Merryfield W.J. (2011), Carbon emission limits required to satisfy future representative concentration pathways of greenhouse gases, Geophysical Research Letters, 38, L05805, doi:10.1029/2010GL046270.

Bristow K.I. and Campbell G.S. (1984), On the relationship between incoming solar radiation and daily maximum and minimum temperature, Agriculture and Forest Meteorology, 31, 159-166.

Chen J. and Brissete F.P. (2014), Comparison of five stochastic weather generators in simulating daily precipitation and temperature for the Loess Plateau of China, International Journal of Climatology, 34, 3089-3105.

Dingman S.L. (2015), Physical Hydrology, Third Edition, Waveland Press, Long Grove, Illinois, USA.

Dufresne J.-L., Foujols M.-A., Denvil S., Caubel A., Marti O., Aumont O., Balkanski Y., Bekki S., Bellenger H., Benshila R., 
Bony S., Bopp L., Braconnot P., Brockmann P., Cadule P., Cheruy F., Codron F., Cozic A., Cugnet D., de Noblet N., Duvel J.-P., Ethé C., Fairhead L., Fichefet T., Flavoni S., Friedlingstein P., Grandpeix J.-Y., Guez L., Guilyardi E., Hauglustaine D., Hourdin F., Idelkadi A., Ghattas J., Joussaume S., Kageyama M., Krinner G., Labetoulle S., Lahellec A., Lefebvre M.-P., Lefevre F., Levy C., Li Z.X., Lloyd J., Lott F., Madec G., Mancip M., Marchand M., Masson S., Meurdesoif Y., Mignot J., Musat I., Parouty S., Polcher J., Rio C., Schulz M., Swingedouw D., Szopa S., Talandier C., Terray P., Viony N. and Vuichard N. (2013), Climate change projections using the IPSL-CM5 Earth System Model: from CMIP3 to CMIP5, Climate Dynamics, 40, 2123-2165.

Dunne J.P., John J.G., Shevliakova E., Stouffer R.J., Krasting J.P., Malyshev S.L., Milly P.C.D., Sentman L.T., Adcroft A.J., Cooke W., Dunne K.A., Griffies S.M., Hallberg R.W., Harrison M.J., Levy H., Wittenberg A.T., Phillips P.J. and Zadeh N. (2013), GFDL's ESM2 Global Coupled Climate - Carbon Earth System Models. Part II: Carbon system formulation and baseline simulation characteristics, Journal of Climate, 26, 22472267.

Flato G. (2011), Earth system models: an overview, Wiley Interdisciplinary Reviews: Climate Change, 2(6), 783-800.

Georgiou P.E. and Karpouzos D.K. (2017), Optimal irrigation water management for adaptation to climate change, International Journal of Sustainable Agricultural Management and Informatics, 3(4), 271-285.

Georgiou P.E. and Papamichail D.M. (2008), Optimization model of an irrigation reservoir for water allocation and crop planting under various weather conditions, Irrigation Science, 7, 85-95.

Guo D., Westra S. and Maier H.R. (2017), Sensitivity of reference evapotranspiration to changes in climate variables for different Australian climatic zones, Hydrology and Earth System Sciences, 421, 2107-2126.

IPPC (2000), Special report on emissions scenarios. A special report of Working Group III of the Intergovernmental Panel on Climate Change, Nakicenovic N., Alcamo J., Grubler A., Riahi K., Roehrl R.A., Rogner H.-H. and Victor N. (Eds), Cambridge University Press, Cambridge, UK.

IPCC (2007), Climate change 2007: Impacts, adaptation and vulnerability, In: Contribution of Working Group II to the Fourth Assessment Report of the Intergovernmental Panel on Climate Change, Parry M.L., Canziani O.F., Palutikof J.P., van der Linden P.J. and Hanson C.E. (Eds), Cambridge University Press, Cambridge, UK.

IPCC (2008), Climate Change and Water, In: Technical paper if the Intergovernmental Panel on climate change, Bates B.C., Kundzewicz Z.W., Wu S. and Palutikof J.P. (Eds.), IPCC Secretariat, Geneva, Switzerland.

IPCC (2013), Climate Change 2013: The physical science basis, In: Contribution of Working Group I to the Fifth Assessment Report of the Intergovernmental Panel on Climate Change, Stocker T.F., Qin D., Plattner G.-K., Tignor M., Allen S.K., Boschung J., Nauels A., Xia Y., Bex V. and Midgley P.M. (Eds.), Cambridge, United Kingdom and New York, NY, USA.

Kingston G., Todd M.C., Taylor R.G., Thompson J.R. and Amell N.W. (2009), Uncertainty in the estimation of reference evapotranspiration under climate change, Geophysical Research Letters, 36, L20403, doi:10.1029/2009GL040267.
Koukouli P. and Georgiou P. (2018), Evaluation of climate change impacts on cotton yield using CropSyst and regression models, Journal of Advances in Agriculture, 8(1), 1433-1451.

Koukouli P., Georgiou P. and Karpouzos D. (2018a), Assessing the hydrological effect of climate change on water balance of a River Basin in Northern Greece, International Journal of Agricultural and Environmental Information Systems International Journal of Agricultural and Environmental Information Systems, 9(4), 14-34.

Koukouli P., Georgiou P. and Karpouzos D. (2018b), Reference evapotranspiration assessment in Chalkidiki region under climate change using four Earth System Models. Proceedings of International Conference Protection and Restoration of the Environment XIV, Thessaloniki, Greece, 3-6 July 2018, 678687.

Lambert S.J. and Boer G.J. (2001), CMIP1 Evaluation and intercomparison of coupled climate models. Climate Dynamics, 17, 83-106.

Lu J., Sun G., McNulty S.G. and Amatya D.M. (2005), A comparison of six potential evapotraspiration methods for regional use in the Southeastern United States, Journal of the American Water Resources Association, 41(3), 621-633.

Martin G.M., Bellouin N., Collins W.J., Culverwell I.D., Halloran P.R., Hardiman S.C., Hinton T.J., Jones C.D., McDonald R.E., McLaren A.J., O'Connor F.M., Roberts M.J., Rodriguez J.M., Woodward S., Best M.J., Brooks M.E., Brown A.R., Butchart N., Dearden C., Derbyshire S.H., Dharssi I., DoutriauxBoucher M., Edwards J.M., Falloon P.D., Gedney N., Gray L.J., Hewitt H.T., Hobson M., Huddleston M.R., Hughes J., Ineson S., Ingram W.J., James P.M., Johns T.C., Johnson C.E., Jones A., Jones C.P., Joshi M.M., Keen A.B., Liddicoat S., Lock A.P., Maidens A.V., Manners J.C., Milton S.F., Rae J.G.L., Ridley J.K., Sellar A., Senior C.A., Totterdell I.J., Verhoef A., Vidale P.L. and Wiltshire A. (2011), The HadGEM2 family of Met Office Unified Model climate configurations, Geoscientific Model Development, 4, 723-757.

McKaque K., Rudra R., Ogilvie J., Ahmed I. and Gharabaghi B. (2005), Evaluation of weather generator ClimGen for Southern Ontario. Canadian Water Resources Journal, 4, 315-329.

McMahon T.A., Peel M.C., Lowe L., Srikanthan R. and McVicar T.R. (2013), Estimating actual, potential reference crop and pan evaporation using standard meteorological data: a pragmatic synthesis, Hydrology and Earth System Sciences, 17, 1331-1363.

Prudhomme C., Reynard N. and Crooks S. (2002), Downscaling of global climate models for flood frequency analysis: where are we now? Hydrological Processes, 16, 1137-1150.

Randall D.A., Wood R.A., Bony S., Colman R., Fichefet T., Fyfe J., Kattsov V., Pitman A., Shukla J., Srinivasan J., Stouffer R.J., Sumi A. and Taylor K.E. (2007), Climate models and their evaluation, In: Climate change 2007: The physical science basis. Contribution of Working Group I to the Fourth Assessment Report of the Intergovernmental Panel on Climate Change, Solomon S., Qin D., Manning M., Chen Z., Marquis M., Averyt K.B., Tignor M. and Miller H.L. (Eds.), Cambridge University Press, Cambridge, UK.

Richardson C.W. (1985), Weather simulation for crop management models. Transactions of the ASAE, 28, 16021606. 
Selker J.S. and Haith D.A. (1990), Development and tesying of single-parameter precipitation distributions, Water Resources Research, 26(11), 2733-2740.

Stöckle C.O. and Nelson R.L. (1999), ClimGen: a weather generator program. Biological Systems Engineering Department, Washington State University, Pullman, WA.

van Vuuren D.P., Edmonds J., Kainuma M., Riahi K., Thomson A., Hibbard K., Hurtt G.C., Kram T., Krey V., Lamarque J.-F., Masui T., Meinshausen M., Nakicenovic N., Smith S.J. and Rose S.K. (2011), The representative concentration pathways: an overview, Climatic Change, 109, 5-31.

Xu, C.-Y. (1999), From GCMs to river flow: a review of downscaling methods and hydrologic modeling approaches. Progress in Physical Geography, 23(2), 229-249.

Yang D. and Saenko O.A. (2012), Heat transport and its projected change in CanESM2. Journal of climate, 25, 8148-8163. 